
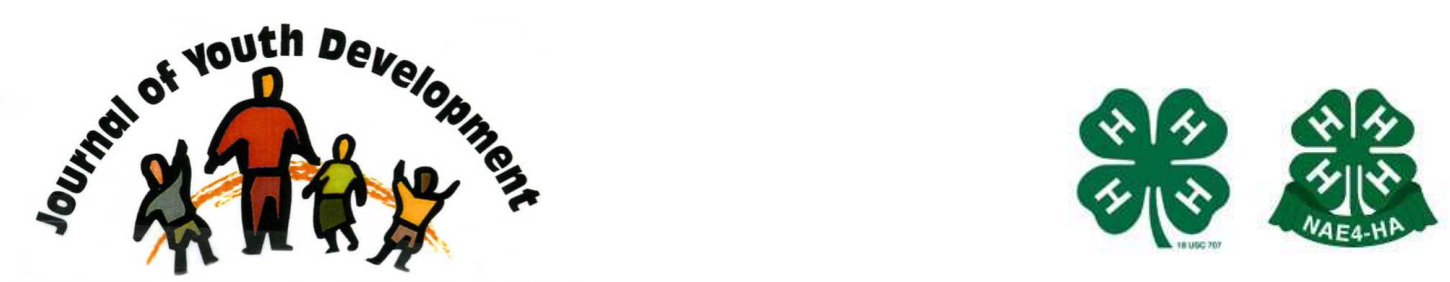

Bridging Research \& Practice

\title{
Resource Review: \\ Youth and Adult Leaders for Program Excellence: A Practical Guide for Program Assessment and Action Planning
}

\author{
Hartley Hobson \\ Vice President \\ Innovation Center for Community and Youth Development
}




\title{
Resource Review: \\ Youth and Adult Leaders for Program Excellence; \\ A Practical Guide for Program Assessment \\ and Action Planning
}

Hartley Hobson

Innovation Center for Community and Youth Development

\begin{abstract}
The Youth and Adult Leaders for Program Excellence (YALPE Resource Kit) was developed to assist groups working to promote positive youth development. The Kit includes a variety of assessment tools and templates for data analysis and report writing. The tools are grounded in research on youth development and are user-friendly for adults and youth.
\end{abstract}

\section{Review}

In many youth programs, staff and participants are not meaningfully involved in program evaluation. A new resource kit, "Youth and Adult Leaders for Program Excellence: A Practical Guide for Program Assessment and Action Planning" has been designed to assist with program evaluation.

The kit includes a step-by-step guide to assessing and improving program quality, specifically the level and impact of youth involvement and the emotional supports, relationships and opportunities provided to youth. Written for older youth or adult readers, the kit can be used by those with or without assessment experience.

The guide is divided into five phases and 12 steps moving from planning to data collection and analysis, to report writing and action planning, giving helpful time estimates for each phase.

The steps support the use of four surveys. Users can select which to use and can add a small number of items to each survey. One survey assesses the quality and impact of youth involvement; another, how well an organization supports youth voice; and two others address 
the supports and opportunities provided to participants. Each survey has been tested with diverse groups and includes a script and details on the purposes of the specific tool.

Excel workbooks (on an included CD) are very useful with detailed instructions for entering data and built-in automatic functions that calculate and produce averages, tables, and graphs. Smartly, the kit also includes forms for hand calculation of results and for compiling and analyzing narrative comments from the surveys. Also of note is an electronic report template (in Word) with instructions on types of information needed in each section of the report.

The kit is written clearly and laid out simply for easy navigating, though page numbers would be helpful. It comes in a 2" 3 ring binder with 140 pages, including appendices.

The kit is not a complete evaluation manual, nor does it claim to be. It assumes that users have already decided to examine the quality of youth engagement and opportunities and supports for youth, but need help in following through. Organizations that need assistance developing and implementing an evaluation plan or a logic model to decide which outcomes are important to assess or determining if the right activities are being done to support outcomes, for example, will not be served by this tool kit. It also does not offer help in defining indicators or considering different assessment methods.

The kit can be ordered for $\$ 61.50$ (including shipping; check or money order only) by downloading the order form from www.actforyouth.net

\section{References}

Camino, L., Zeldin, S., Mook, C. \& O'Connor, C. (2004). Youth and Adult Leaders for Program Excellence: A Practical Guide for Program Assessment and Action Planning. Madison, WI: Community Youth Connection.

(C) Copyright of Journal of Youth Development $\sim$ Bridging Research and Practice. Content may not be copied or emailed to multiple sites or posted to a listserv without copyright holder's express written permission. Contact Editor at: patricia.dawson@oregonstate.edu for details. However, users may print, download or email articles for individual use.

ISSN 2325-4009 (Print); ISSN 2325-4017 (Online) 